\title{
1-1-23 遺伝性難㯖の研究
}

\section{立木孝（岩医大） \\ 村井盛子 \\ ○佐蔇鿁人}

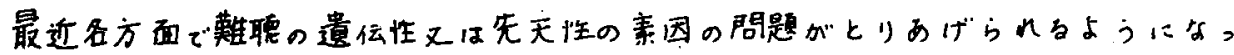

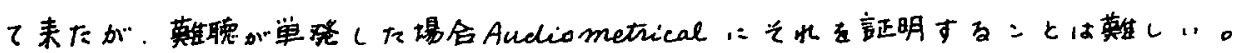

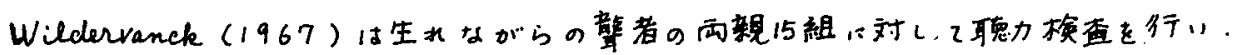

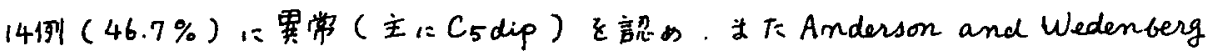

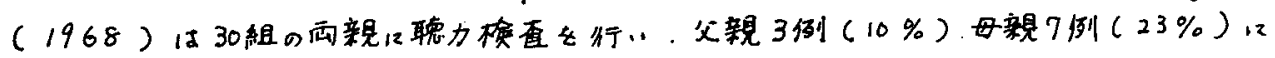

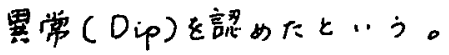

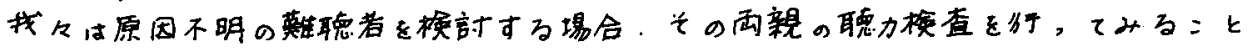
が一つの方法ではぬからうかと考えた。

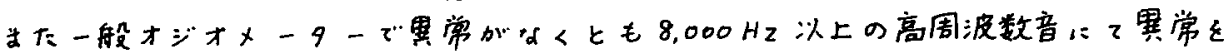

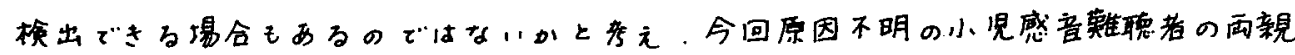
詨して，現在の標㴖オージオメトり一の他に10 KHz 〜 $18 \mathrm{KHz}$ 迄の高周波数の音に ついても梌查し，光の結果を報告した。

観察対象及山゙方法：

原因不明の小児感音難㯖者16名と乞の两親32名を対象とした。

オージオメータ一は10，12，15及び18 KHzの周波数音加笔振できるように改造し たりオンAAー37 オージオイーターを使用いた。

\section{結果：}

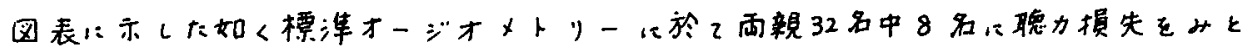

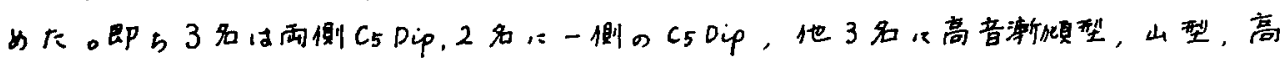
音急墜型の䏇力損失を言忍心下。

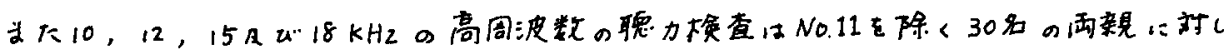

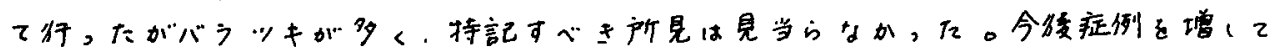
娭討可る必要があると思う。 


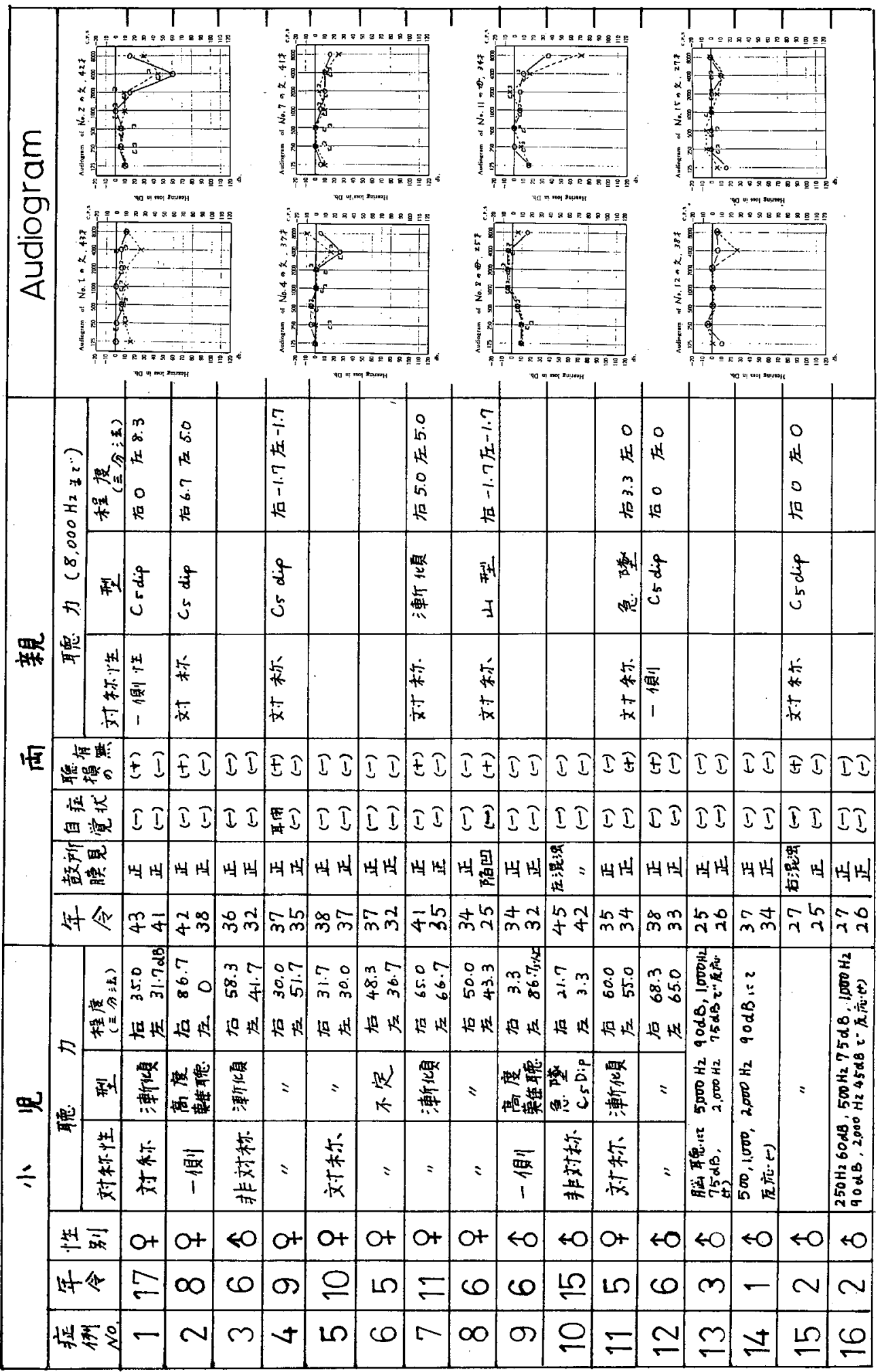

